Acta technologica agriculturae 1

Nitra, Slovaca Universitas Agriculturae Nitriae, 2013, p. 18-21

\title{
EVALUATION OF FUEL CONSUMPTION IN ROAD FREIGHT TRANSPORT
}

\author{
Mário SZABÓ, Radoslav MAJDAN, Zdenko TKÁČ, Rastislav ČÁPORA, L’ubomír HUJO \\ Slovak University of Agriculture in Nitra, Slovakia
}

\begin{abstract}
This paper deals with the importance of fuel economy in road freight transport. It provides the calculation of financial savings for fuel savings of $0.5 \mathrm{I}$ per $100 \mathrm{~km}$. In the subsequent part, some factors that influence the fuel consumption are specified, e.g. aerodynamic resistance, rolling resistance, and tyre inflation pressure. The effect of tyre inflation pressure on fuel economy has been tested on four selected towing vehicles. Based on the results obtained, it can be stated that tyre pressure has a great impact on fuel consumption. A one-bar pressure reduction of tyres can increase the fuel consumption by $0.5 \mathrm{I}$ per $100 \mathrm{~km}$.
\end{abstract}

Keywords: aerodynamic resistance, rolling resistance, tyre inflation pressure, fuel consumption

There has been a growing number of vehicles on our roads recently. Lorries are the main source of air pollution (Lendák, 2008). Figure 1 shows that the number of lorries is growing from year to year.

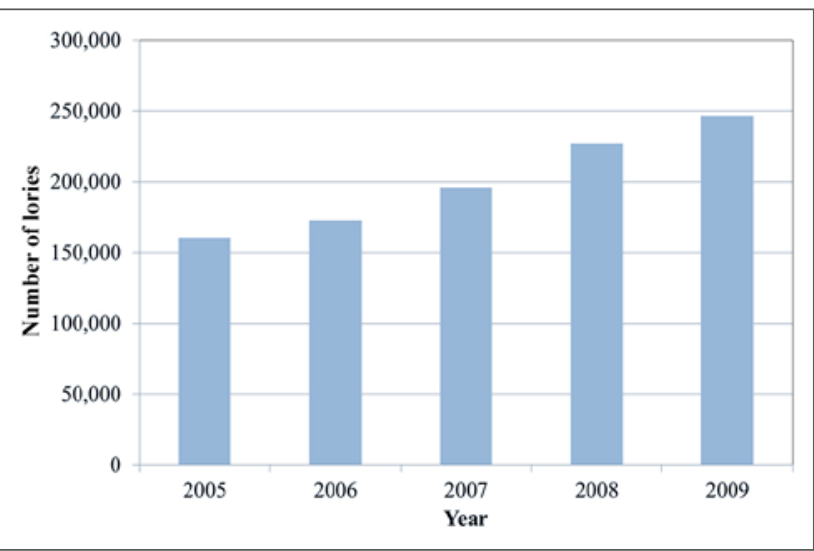

Figure 1 Development of the number of lorries in Slovakia Source: O peniazoch, 2012

According to Vitázek (2006), the exploitation of primary energy sources negatively affects the environment in case of extraction and fuel treatment, but primarily in the transformation of one type of energy into the other. The reducing of fuel consumption has ecological as well as economic reasons.

Modern towing vehicles used today have an engine power of $330 \mathrm{~kW}$, which is equal to approximately 460 horsepower.
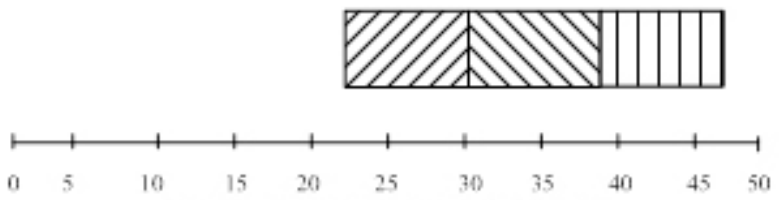

fuel consumption in $\mathrm{l} / 100 \mathrm{~km}$

D good $\square$ average mbad

Figure 2 Reference values of fuel consumption for vehicles from 381 h.p. to 480 h.p.

Source: Energeco, 2011
Based on engine power, it is possible to determine the fuel consumption for particular types of lorries.

In addition to fuel consumption, which is necessary for towing vehicles to run, also excessive fuel consumption is likely to occur in practice. The amount of excessive consumption is influenced by many factors. As the fuel price is increasing dramatically, it is important to recognise these factors and to minimise the fuel consumption.

Apart from the engine type, there are also other factors that influence the fuel consumption. There are many factors dependent on the technical condition of vehicles. However, in the following part, we mention only those factors we are able to influence.

Aerodynamic resistance has a great impact on the overall fuel consumption. This resistance can be reduced considerably by a correct use of spoilers and aerodynamic stabilisers. However, when used unprofessionally, spoilers can increase the fuel consumption.

Based on the research carried out by the Renault and Michelin companies, the rolling resistance of tyres represents approximately one third of the overall power of resistance to motion. The tyre warms up during the drive, which is caused by bend stress (bend of the tyre side, bend of the tyre tread). Tyre bend causes friction that releases heat. That heat is the energy that the engine has to overcome. It is one of the fuel consumption factors (Liščák, 2004).

By keeping the recommended tyre pressure, the vehicle maintains an optimal output of tyres as well as optimal fuel economy. Moreover, the overall driving is more comfortable, and the life of tyres is longer. On the contrary, a lower pressure in tyres causes that the contact surface between the vehicle and the road surface is larger, and the tyre sides become more worn-out. A higher temperature in tyres is connected with a higher rolling resistance. Therefore, an optimal tyre pressure stabilises their structure, drive and the response of tyres to a change in direction.

In Slovakia, the fuel price is rising constantly, and the situation on a current international market does not predict that the fuel price is likely to be reduced. Even though we cannot predict the fuel price in the near future, the tendency is that the fuel price is likely to rise rather than to fall (Schlosser, 2001). 
Table 1 Fuel price development

\begin{tabular}{|l||c|}
\hline Date & Fuel price in $€$ \\
\hline \hline 1 September 2010 & 1.124 \\
\hline 1 May 2011 & 1.376 \\
\hline 1 January 2012 & 1.392 \\
\hline 1 September 2012 & 1.495 \\
\hline
\end{tabular}

By a gradual improvement in the development of vehicles, the overall effectiveness of combustion engines increases. As a consequence, fuel consumption is reduced (fuel consumption per unit of power). Moreover, there has recently been a rise in an active, passive and environmental safety of newly manufactured vehicles (Lendák, 2008).

The recent fuel consumption can be evaluated based on data from vehicle information systems. Janoško (1996) and Janoško et al. (1996) state that more precise consumption data are to be obtained by means of specially designed devices for a particular type of vehicle.

\section{Material and methods}

The calculation of fuel consumption:

Fuel consumption in a transport company can be calculated as follows:

$$
V=s \cdot S p
$$

where:

$V$ - monthly fuel consumption, I

$s$ - monthly distance covered, $\mathrm{km}$

Sp - average consumption, $1 / 100 \mathrm{~km}$

Fuel cost savings can be calculated as follows:

$$
F=A \cdot N \cdot M U ́
$$

where:

$F$ - monthly savings, EUR

A - number of vehicles, pcs

$N$ - current fuel price, EUR/I

$M U ́$ - monthly fuel savings of one vehicle, I

\section{Description of a transport company and monitored lorries}

The object of our study was the group of lorries of ZANO TRANS, s. r. o. (private limited company). This company deals with international and domestic transport by camions up to $24 \mathrm{t}$.

The vehicle fleet of the company consists of 25 Renault vehicles. Five of them are of the Renault Magnum type, and 20 of them are Renault Premium Route. These vehicles were observed in the period from year 2010 to year 2012. All the data were collected by means of an Infomax information system.

Research tests were carried out on four selected vehicles within domestic transport by camions. Because of space limitations, we introduce the technical specifications for vehicle No 4 only, see Table 2.

\begin{tabular}{|c|c|c|}
\hline Type & \multicolumn{2}{|c|}{ Lorry - semi-trailer towing vehicle } \\
\hline Category & \multicolumn{2}{|c|}{ N3 } \\
\hline Make & \multicolumn{2}{|c|}{ Renault } \\
\hline Trade name & \multicolumn{2}{|c|}{ Magnum 460} \\
\hline Engine & \multicolumn{2}{|c|}{ DXI 13EC06B-TR40 } \\
\hline \multicolumn{3}{|c|}{ Technical specifications of vehicle No 4} \\
\hline Specification & Value & Unit \\
\hline Displacement & 12,780 & $\mathrm{~cm} 3$ \\
\hline Max. power & 338 & kW \\
\hline \multicolumn{3}{|c|}{ Overall size } \\
\hline Length & 5,910 & $\mathrm{~mm}$ \\
\hline Width & 2,550 & $\mathrm{~mm}$ \\
\hline Height & 4,000 & $\mathrm{~mm}$ \\
\hline Service weight & 8,330 & $\mathrm{~kg}$ \\
\hline
\end{tabular}

Table 2 Technical specifications of vehicle No 4

\section{Effect of tyre inflation pressure on fuel consumption}

The audit of tyre condition was carried out in ZANO TRANS, s. r. o. on 29 October 2011. The pressure and tread pattern of tyres was investigated by an external company. Serious deficiencies were discovered during this audit because the majority of tyres were under-inflated. Some of the tyres were inflated only up to 4.6 bars instead of 9.0 bars recommended by the manufacturer.

Upon request of the company, we checked the tyre pressure of randomly selected vehicles on 4 March 2012. This measurement was performed between 14:00 and 16:00. The air temperature during the measurement was $14^{\circ} \mathrm{C}$.

In order to compare the effect of tyre pressure on fuel consumption, the tyre pressure of each vehicle was averaged according to the following equation:

$$
x=\frac{\sum_{i=1}^{n} x_{i}}{n}
$$

where:

$x \quad$ - average pressure of tyres, MPa

$n$ - number of wheels

The measurement was carried out using a Schneider MAST'AIR S 25 pressure gauge.

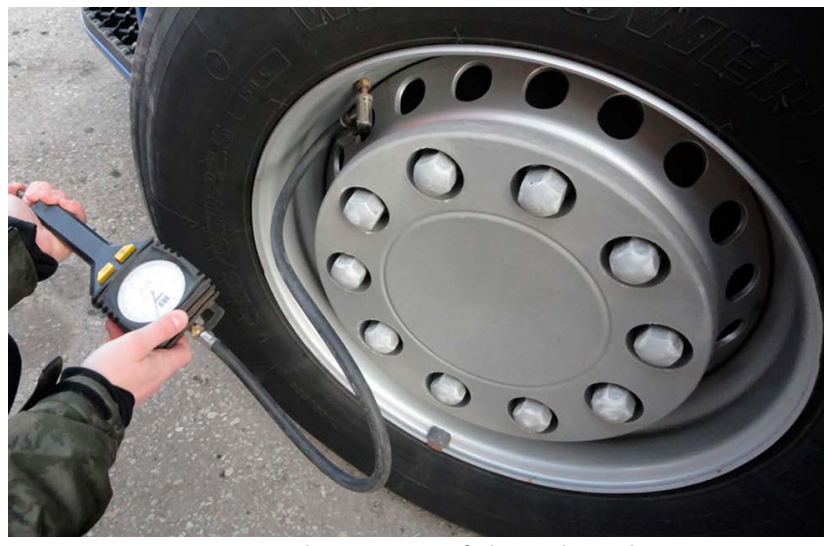

Figure 3 Measuring by means of the Schneider MAST'AIR S 25 pressure gauge 


\section{Results and discussion}

\section{Effect of tyre inflation pressure on fuel consumption}

Based on the above-mentioned methodology, we have measured the tyre pressure and its effect on fuel consumption.

Table 3 shows the values of vehicle No 4 (on 4 March 2012 and 29 October 2011), more concretely, pressure values, the values of fuel consumption in a particular period, and the tyre inflation pressure recommended by the manufacturer.

The audit carried out on 29 October 2011 revealed that the tyres of vehicle No 4 were under-inflated. The average fuel consumption of this vehicle was $33.8 \mathrm{l} / 100 \mathrm{~km}$.

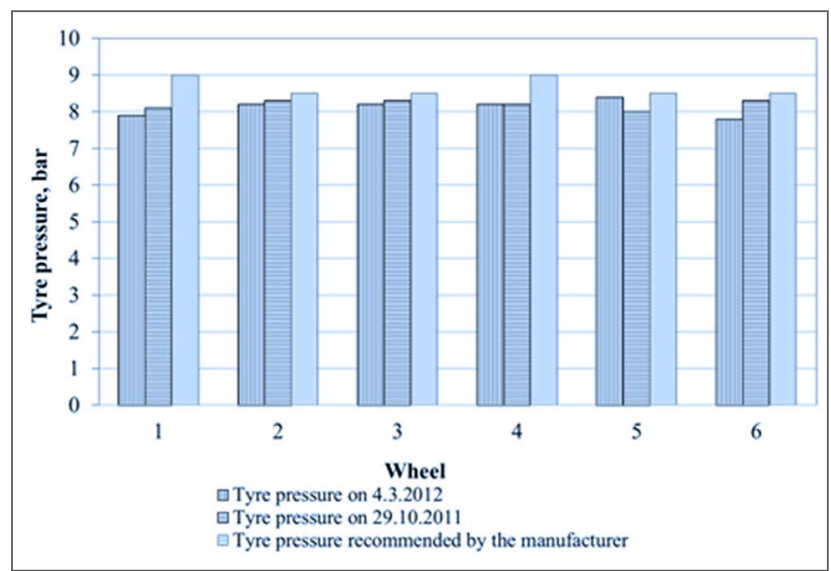

Figure 4 Comparison of tyre pressure in vehicle No 4
Based on inspection, we learnt that the calculated average tyre pressure dropped from 8.2 bars to 8.12 bars. This fact caused that fuel consumption increased by 0.5 $\mathrm{l} / 100 \mathrm{~km}$.

\section{Analysing the effect of tyre inflation pressure on fuel consumption in other vehicles}

Table 4 shows the pressure values in other vehicles (on 4 March 2012 and 29 October 2011), more concretely, pressure values and the values of fuel consumption in a particular period.

Four vehicles were compared in total. As obvious from Figure 5, the tyre pressure of vehicles No 1 and 3 was higher during the second measurement (29 October 2011), and fuel consumption was lower. On the other hand, vehicles No 2 and 4 had a lower tyre pressure during the second measurement. As a result, their fuel consumption was higher.

\section{Savings in the circulation of lorries}

As evident from Figure 2, the average fuel consumption of a fully loaded lorry is approximately $35 \mathrm{l} / 100 \mathrm{~km}$.

The vehicles of ZANO TRANS, s. r. o. run from $10,000 \mathrm{~km}$ up to $15,000 \mathrm{~km}$ monthly. Taking into account a covered distance of $12,000 \mathrm{~km}$, fuel consumption can be calculated according to Equation (1), and it would be 4,200 I. Based on the results of this study, it is possible to save $0.5 \mathrm{I}$ of fuel per $100 \mathrm{~km}$ by a correct tyre inflation pressure, representing the monthly fuel savings of $60 \mathrm{I}$ per one vehicle.

The majority of transport companies own tens of lorries. Consequently, these figures are even higher. When counting

Table 3 Measured values of tyre pressure in vehicle No 4

\begin{tabular}{|l||c|c|c|}
\hline \multicolumn{4}{|c|}{ Vehicle No 4 } \\
\hline Wheel & $\begin{array}{c}\text { Tyre pressure } \\
\mathbf{4 . 3 . 2 0 1 2}\end{array}$ & $\begin{array}{c}\text { Tyre pressure } \\
\mathbf{2 9 . 1 0 . 2 0 1 1}\end{array}$ & $\begin{array}{c}\text { Pressure recommended } \\
\text { by the manufacturer }\end{array}$ \\
\hline \hline & Bar & Bar & Bar \\
\hline 1 & 7.9 & 8.1 & 8.5 \\
\hline 2 & 8.2 & 8.3 & 8.5 \\
\hline 4 & 8.2 & 8.3 & 9 \\
\hline 5 & 8.2 & 8.2 & 8.5 \\
\hline 6 & 8.4 & 8 & 8.5 \\
\hline Calculated average value & 7.8 & 8.3 & 8.67 \\
\hline Consumption according to Infomax $(\mathrm{I} / 100 \mathrm{~km})$ & 8.12 & 8.20 & 3.8 \\
\hline
\end{tabular}

Table 4 Measured values of tyre inflation pressure

\begin{tabular}{|l||c|c|c|c|c|c|}
\hline Vehicles & $\begin{array}{c}\mathbf{4 . 3 . 2 0 1 2} \\
\text { Average tyre } \\
\text { pressure in bar }\end{array}$ & $\begin{array}{c}\mathbf{4 . 2 . 2 0 1 2} \text { - 4.3.2012 } \\
\text { Fuel consumption } \\
\text { in I/100 km }\end{array}$ & $\begin{array}{c}\mathbf{2 9 . 1 0 . 2 0 1 1} \\
\text { Average tyre } \\
\text { pressure in bar }\end{array}$ & $\begin{array}{c}\mathbf{2 9 . 9 . 2 0 1 1 - 2 9 . 1 0 . 2 0 1 1} \\
\text { Fuel consumption } \\
\text { in I/100 km }\end{array}$ & $\begin{array}{c}\text { Tyre pressure } \\
\text { difference } \\
\text { in bar }\end{array}$ & $\begin{array}{c}\text { Fuel consumption } \\
\text { difference } \\
\text { in I/100 km }\end{array}$ \\
\hline \hline 1 & 9.15 & 34.8 & 7.83 & 35 & 1.32 & -0.2 \\
\hline 2 & 8.12 & 34.3 & 8.2 & 33.8 & -0.08 & 0.5 \\
\hline 3 & 7.97 & 35.8 & 7.45 & 37.2 & 0.52 & -1.4 \\
\hline 4 & 8.07 & 32.5 & 8.23 & 32.3 & -0.16 & 0.2 \\
\hline
\end{tabular}




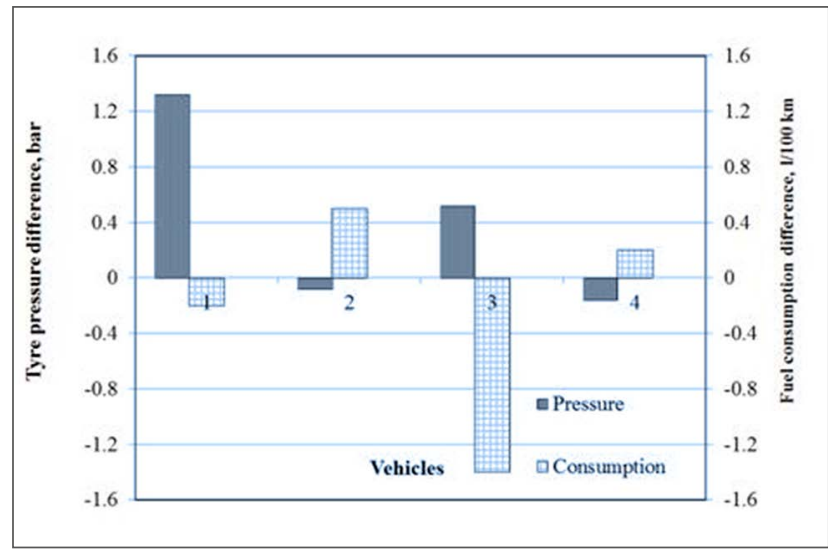

Figure 5 Tyre pressure and fuel consumption differences

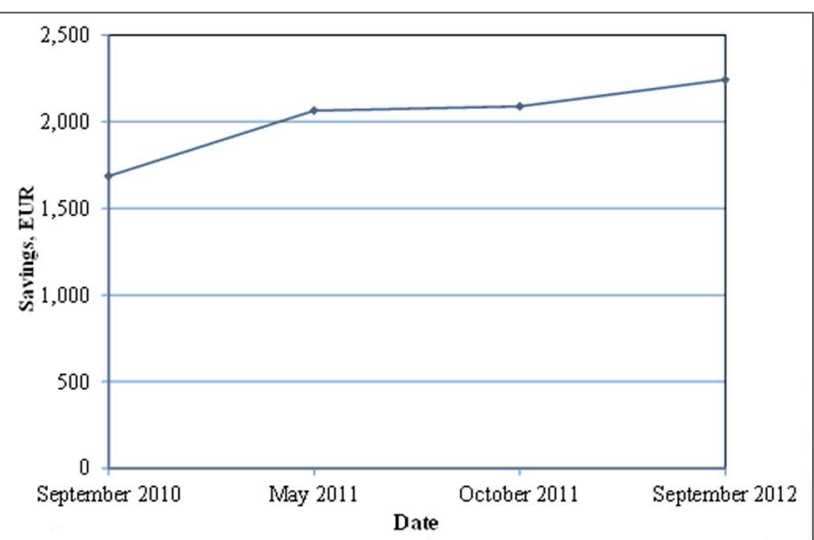

Figure 6 Development of monthly savings (from September 2010 till September 2012)

for 25 vehicles, with a current fuel price of 1.495 EUR/l, the monthly savings could be EUR 2,242.50.

Figure 6 shows that monthly savings are increasing annually, and it is predicted that these savings tend to grow in the future.

\section{Conclusion}

This paper deals with the analysis of factors affecting the fuel consumption in road freight transport and with verifying the effect of tyre inflation pressure on fuel consumption.

Based on measured values, it is possible to state that tyre pressure has a considerable effect on fuel consumption. Four vehicles were tested. An external company carried out the first measurement of tyre pressure on 29 October 2011. The second measurement was performed by us using the above-mentioned methodology.

It has been proved with all the tested vehicles that fuel consumption was higher when tyres were under-inflated. The tyre pressure of vehicle No 7 was closest to the pressure of 8.67 bars recommended by the manufacturer, and had the most optimal fuel consumption.

\section{Acknowledgements}

This paper was prepared with the support of the Ministry of Education of the Slovak Republic, project VEGA 1/0857/12 'Reduction of unfavourable impacts of agricultural and transport machinery on the environment'.

\section{References}

ENERGECO. 2011. [online] [cit.2012-02-11]. Available on the Internet: http://www.energeco.org/index.php?page=projet\&p=2_1_3_0

JANOŠKO, I. 1996. Snímanie a monitorovanie spotreby paliva. In Zemědělská technika, roč. 42, 1996, č. 3, s. 93-98. ISSN 0044-3883.

JANOŠKO, J. - DRABANT, Š. - CALEK, M. 1996. Meranie spotreby paliva naftových motorov objemovou metódou. In Acta technologica agriculturae, roč. 37, 1996, s. 37-43. ISSN 80-7137-319-2.

LENĎÁK, P. - JABLONICKÝ, J. - BOHÁT, M. - ŠVEC, J. 2008. Ekologická bezpečnost' motorových vozidiel v prevádzke. In VOZIDLÁ 2008 [CD]. Nitra : SPU, s. 111-118. ISBN 978-80-552-0106-1.

LIŠČÁK, Š. et al. 2004. Prevádzkové charakteristiky vozidiel. 1. vyd. Žilina : Žilinská univerzita. 177 s. ISBN 80-8070-247-0.

O PENIAZOCH. 2012. [online] [cit. 2012-02-11]. Available on the Internet: http://openiazoch.zoznam.sk/zivot/makro/benzin.asp Program instructions: Renault Infomax

SCHLOSSER, T. et al. 2001. Inteligentné dopravné systémy. 1. vyd. Bratislava : Publisher Jaga Group. 198 s. ISBN 80-88905-64.

VITÁZEK, I. 2006. Tepelné procesy v plynnom prostredí. 1. vyd. Nitra : SPU. 98 s. ISBN 80-8069-716-7.

\section{Contact address:}

Ing. Mário Szabó; Ing. Radoslav Majdan, PhD.; prof. Ing. Zdenko Tkáč, PhD.; Ing. Rastislav Čápora, Ing. Luubomír Hujo, PhD.; Department of Transport and Handling, Faculty of Engineering, Slovak University of Agriculture in Nitra, Tr. Andrejra Hlinku 2, 94976 Nitra, Slovakia, e-mail: szabo@dtx.sk 